- Impressions of teeth and implants are differentiated.

- Accuracy of different impression copings and methods are discussed.

- Methods to transfer peri implant soft tissues are illustrated.

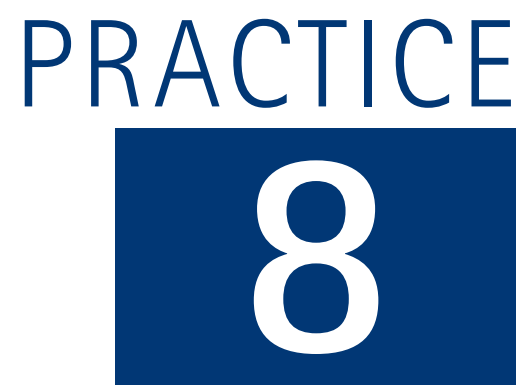

\title{
Impression techniques for implant dentistry
}

\author{
W. Chee ${ }^{1}$ and S. Jivraj ${ }^{2}$
}

\begin{abstract}
The object of making an impression in implant dentistry is to accurately relate an analogue of the implant or implant abutment to the other structures in the dental arch. This is affected by use of an impression coping which is attached to the implant or implant abutment. This impression coping is incorporated in an impression - much as a metal framework is 'picked up' in a remount impression for fixed prosthodontics. With implant copings the coping is usually attached to the implant or abutment with screws. The impression material used is usually an elastomeric impression material; the two types most widely used and shown to be the most appropriate are polyether and polyvinyl siloxane impression materials. ${ }^{1}$
\end{abstract}

\begin{tabular}{|c|}
\hline IMPLANTS \\
\hline 1. Rationale for dental implants \\
\hline $\begin{array}{l}\text { 2. Treatment planning of implants in } \\
\text { posterior quadrants }\end{array}$ \\
\hline $\begin{array}{l}\text { 3. Treatment planning of implants in } \\
\text { the aesthetic zone }\end{array}$ \\
\hline $\begin{array}{l}\text { 4. Surgical guidelines for dental } \\
\text { implant placement }\end{array}$ \\
\hline $\begin{array}{l}\text { 5. Immediate implant placement: } \\
\text { treatment planning and surgical steps } \\
\text { for successful outcomes }\end{array}$ \\
\hline $\begin{array}{l}\text { 6. Treatment planning of the } \\
\text { edentulous maxilla }\end{array}$ \\
\hline $\begin{array}{l}\text { 7. Treatment planning of the } \\
\text { edentulous mandible }\end{array}$ \\
\hline $\begin{array}{l}\text { 8. Impression techniques for implant } \\
\text { dentistry }\end{array}$ \\
\hline $\begin{array}{l}\text { 9. Screw versus cemented implant } \\
\text { supported restorations }\end{array}$ \\
\hline $\begin{array}{l}\text { 10. Designing abutments for } \\
\text { cement retained implant supported } \\
\text { restorations }\end{array}$ \\
\hline 11. Connecting implants to teeth \\
\hline $\begin{array}{l}\text { 12. Transitioning a patient from teeth } \\
\text { to implants }\end{array}$ \\
\hline $\begin{array}{l}\text { 13. The role of orthodontics in implant } \\
\text { dentistry }\end{array}$ \\
\hline $\begin{array}{l}\text { 14. Interdisciplinary approach to } \\
\text { implant dentistry }\end{array}$ \\
\hline $\begin{array}{l}\text { 15. Factors that affect individual } \\
\text { tooth prognosis and choices in } \\
\text { contemporary treatment planning }\end{array}$ \\
\hline 16. Maintenance and failures \\
\hline
\end{tabular}

The impression coping takes two general forms, one type is retained in the mouth when the set impression is removed - this type of impression coping is known as the transfer type impression coping. The other type is incorporated in the impression and is removed from the mouth together with the set impression and is known as a pick up type impression coping.

Characteristics or the transfer type impression coping are that they remain in the mouth on removal of the set impression, the analogue is attached to the impression coping after removal from the mouth and this assembly is replaced in the indentation left on the set impression. No custom tray is required for this type of impression.

\footnotetext{
1*Ralph W. and Jean L. Bleak Professor of Restorative Dentistry, Director of Implant Dentistry at the University of Southern California School of Dentistry / Private Prosthodontics Practitioner, Pasadena, California; ${ }^{2}$ Chairman, Section of Fixed Prosthodontics and Operative Dentistry, University of Southern California School of Dentistry / Private Prosthodontics Practitioner, Torrance, California

${ }^{*}$ Correspondence to: Dr Winston Chee, School of Dentistry Rm4374, University Park, University of Southern California, Los Angeles, CA 90089-0641, USA

Email:wchee@usc.edu
}

\section{Refereed Paper}

(c) British Dental Journal 2006; 201 : 429-432

DOI: $10.1038 /$ sj.bdj.4814118
Characteristics of the pick up type impression coping are that they are removed from the mouth together with the set impression. They require access to the retaining screw to allow release of the screw prior to removal of the impression coping - impression assembly, the analogues are attached to the impression copings while they are embedded in the impression tray. A custom tray with access to the impression coping screws is required.

Some precautions to take are:

- Making a radiograph when the impression coping/implant or impression coping/abutment is below the level of the mucosa to insure seating of the impression copings.

- Using vinyl gloves when a polyvinyl siloxane impression is used to prevent retardation of setting of the impression material from the interaction of latex gloves with the material. ${ }^{2,3}$

- It has been shown that the pick up type impression coping is the more accurate type of impression as errors occur on removal and replacement of the transfer type impression copings, especially in the occluso-gingival direction. $^{4-7}$

However, there are indications to use of the transfer type impression coping. When there is limited mouth opening they can be used as there may not be sufficient space for access to the screws retaining pick up type impression 
Fig. 1 Intra oral view of transfer impression coping in place.

Fig. 2 Transfer impression analogue assembly placed into elastormeric impression.
Fig. 3 Cast of implant analogue with soft tissue cast removed - allowing the technician access to the fit surface of the implant analogue.

Fig. 4 Completed restoration in occlusion on working casts.

Fig. 5 Radiograph of restoration indicating poor seating due to interference of inter proximal contacts.

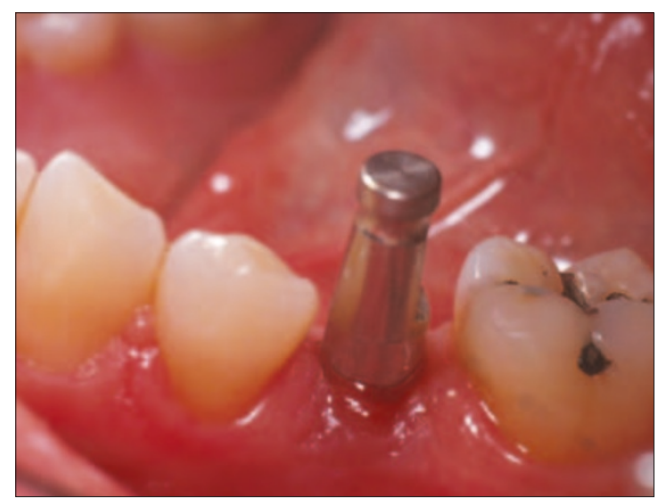

copings with the impression in place and in patients with an exaggerated gag reflex, when the impression has to be removed as quickly as possible.

The fidelity of the impression with respect to dimensional stability is critical; small discrepancies can lead to difficulty when the restoration is fabricated and delivered. Figures 1 to 7 illustrate a situation where a transfer type impression coping was used, showing that a slight error resulted in poor seating of the restoration due to interference with the proximal contacts. The impression was repeated with a pick up type impression and the contacts refined to allow more efficient delivery of the finished restoration with minimal adjustments to the interproximal contacts. These errors are more obvious when compared to conventional fixed prosthodontics due to the precise machine fit of implant components and to the rigid connection of implant to bone. Any discrepancy of the working cast to the mouth will manifest itself (Figs 1-7)

When impressions are required for multi implant restorations the precision of the impression is even more critical. This is because frameworks will be constructed from the master cast and mis-fit in the frameworks can lead to stress applied to the implants on screwing down the framework. Bone loss and even loss of integration has been attributed to this misfit.

Many articles have been written and many in vivo studies have been carried out to improve the fidelity of impressions over the use of pick up type impression copings alone. Some advocate connecting the impression copings together intra orally prior to impression making with acrylic resin. ${ }^{8}$ These studies indicate that there is not statistically significant improvement when splinting impression copings with acrylic, however, the deviation of these impressions from the standardised cast is smaller. Others advocate use of impression plaster to connect the impression copings. ${ }^{9}$ Manufacturers have developed impression copings with 'metal wings' that can be connected with acrylic resin to reduce the bulk of shrinking acrylic to further improve dimensional stability of the impression in order to obtain a passive framework. ${ }^{10}$ Yet others have advocated corrected impression techniques where impression copings are connected then with only one impression coping related to the cast the other analogues are retrofitted to the cast to compensate for distortions of the impression material and the distortions of the setting die master cast material. Other authors have demonstrated that none of the above procedures are likely to improve the fidelity of the impression over use of a rigid custom tray and pick up type impression copings with an elastomeric impression material. ${ }^{11-14}$

Based on the above, the authors' suggestion is to use a an open custom tray which is rigid, to allow access to the retaining screws of pick up impression copings, to use a polyvinyl siloxane 


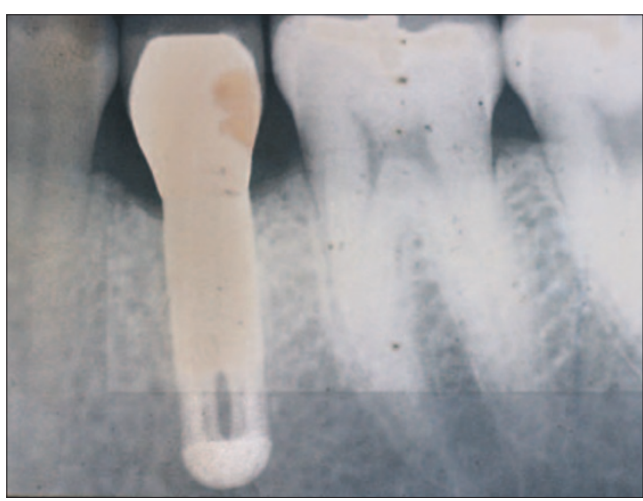

Fig. 6 Radiograph of restoration indicating seating after contacts are adjusted.

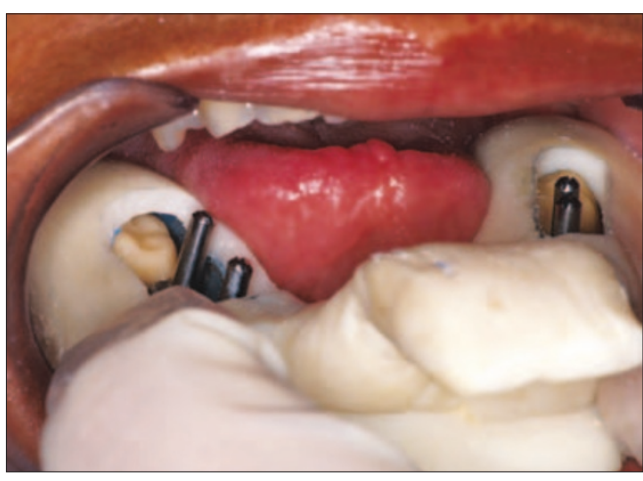

Fig. 8 Intra oral view of pick up impression copings and custom tray.

impression material with adhesive applied to the custom tray and poly ether as a soft tissue cast material (Figs 8-10). ${ }^{15-18}$

The above describes only making an impression which as accurately as possible positions the implant or abutment analogues in the master cast. This only provides the technician with part of the information he or she needs to fabricate the restoration. Other information that the technician will require about the soft tissue contours, that will frame the restoration and provide much of the aesthetics, will come from transfer of the contours surrounding the implant and also pontic areas. ${ }^{19}$ Several methods are available to capture this information on the master cast and they will be discussed as follows:

1. fabricating a custom impression coping which is adapted to the soft tissue contours

2. replacing the provisional restoration on the master cast and forming the soft tissue around the sub muscosal areas of the provisional restoration

3. incorporating the provisional restoration into the impression.

Manufacturer supplied impression copings do not take into account soft tissue morphology formed by provisional restorations. Impressions using manufacturer supplied impression copings merely relate the implant or implant abutment to oral structures. Customised impression copings that accurately record the soft tissue can be made by attaching an analogue to the provision-

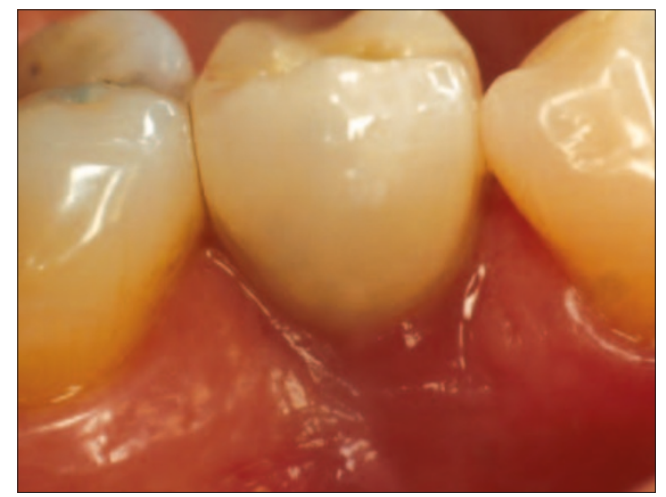

Fig. 7 Intra oral view of seated restoration.

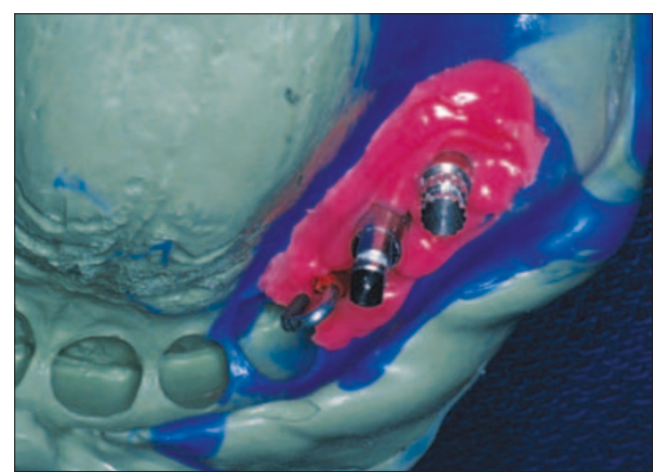

Fig. 9 Impression in Figure 8 with implant analogues assembled and soft tissue cast poured.

al restoration and placing some impression material around the sub mucosal portion of the provisional restoration. On setting of the impression material the provisional restoration can be returned to the patient. An impression coping is attached to the analogue and the space around the impression coping formed by the provisional restoration is filled with acrylic resin. The customised impression coping is then used in the impression making process. A soft tissue cast is poured around the customised impression coping producing a cast with the implant position and soft tissue representing the intra oral conditions. ${ }^{20,21}$

Instead of making customised impression copings, the provisional restoration can be seated on the master cast that is made routinely and the existing soft tissue cast can be removed. The provisional restorations are removed from the patient and placed onto the master cast and impression material is extruded around the provisional restoration to form the soft tissue contours presenting intra orally. ${ }^{22}$

Another method of transferring soft tissue information is incorporating the provisional restoration into the impression. When screw retained restorations are used, the provisional restoration itself can be used as a pick up type impression coping. A soft tissue cast is poured around the exposed provisional after an impression coping is attached, yielding a soft tissue cast which is identical to the soft tissue form intra orally. This allows communication of some vital information to the technician fabricating the definitive restorations (Figs 11-12). ${ }^{23,24}$ 
Fig. 10 Occlusal view of hard and soft tissue cast recovered from impression.

Fig. 11 Impression incorporating provisional restoration - note the sub mucosal portion of the provisional restoration.

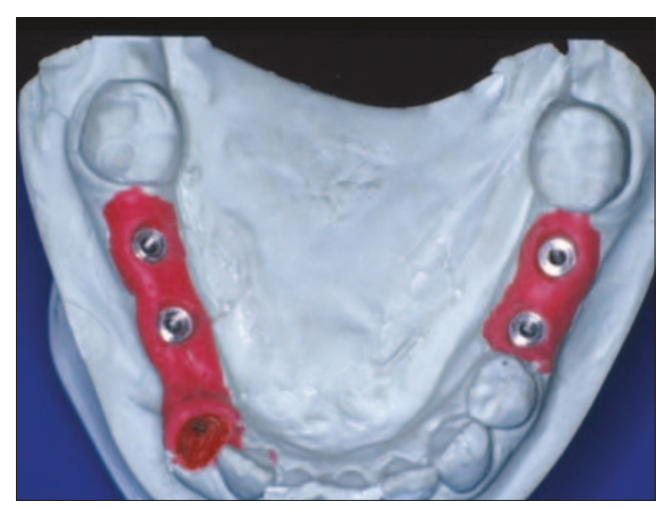

identical to the soft tissue contours present intra orally. Using the modified impression techniques described, information regarding soft tissues can be transferred to the master cast.

1. Wee A. G. Comparison of impression materials for direct multi-implant impressions. J Prosthet Dent 2000: 83: 323-331.

2. Kahn R, Donovan TE, Chee W W. Interaction of gloves and rubber dam with a Poly (Vinyl Siloxane) impression material: A screening test. Int J Prosthodont 1989; 2: 342-346.

3. Chee W W, Donovan TE, Kahn R L. Indirect inhibition of polymerization of a polyvinyl siloxane impression material: a case report Quint Int 1991: 2: 133-135.

4. Liou A D, Nicholls JI, Yuodelis R A, Brudvik J S. Accuracy of replacing three tapered transfer impression copings in two elastomeric impression materials. Int J Prosthodont 1993. 6:377-383.

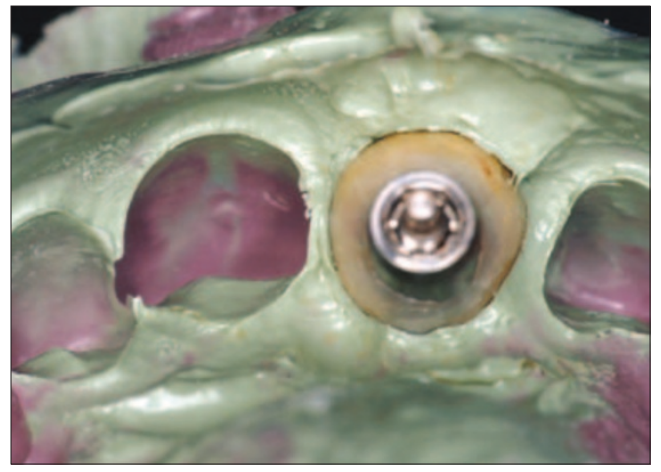

Fig. 12 Cast recovered from impression in Figure 11 with restorative cylinder in place - note the soft tissue information communicated to the laboratory technician.

8. Assif D, Marshak B, Schmidt A. Accuracy of implant

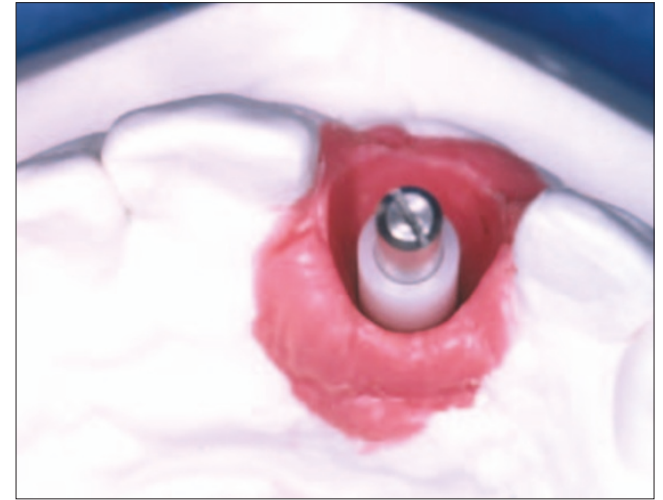

\section{DISCUSSION}

A review of the literature concerning impression making in implant dentistry was presented along with suggestions for a predictable implant impression technique, when esthetics is of concern methods of transferring the soft tissue information formed by provisional restorations to the master cast were also described.

\section{CONCLUSION}

With the predictable integration of implants the emphasis is shifted toward more precision with restorative techniques and the creation of tooth like replacements for missing teeth. With careful planning dental implants can be placed in ideal restorative positions. Furthermore, with careful soft tissue management the soft tissue contours can be enhanced with early use provisional restorations. These efforts must be translated to the master cast to allow the technician to fabricate definitive restorations that have individualised peri implant soft tissue contours that will be
5. Assif D, Fenton A, Zarb G, Schmitt A. Comparative accuracy of implant impression procedures. Int J Perio Rest Dent 1992; 12: 112-121.

6. Barrett M G, de Rijk W G, Burgess J O. The accuracy of six impression techniques for osseointegrated implants. J Prosthodont 1993: 2: 75-82.

7. Spector M R, Donovan TE, Nicholls J I. An evaluation of impression techniques for osseointegrated implants. J Prosthet Dent 1990; 63: 444-447. impression techniques. Int J Oral Maxillofac Implants 1996; 11: 216-222.

9. Assif D, Nissan J, Varsano I, Singer A. Accuracy of implant impression splinted techniques: effect of splinting material. Int J Oral Maxillofac Implants 1999; 14: 885-888.

10. Carr A B, Master J. The accuracy of implant verification casts compared with casts produced from a rigid transfer coping technique. J Prosthodont 1996; 5: 248-252.

11. McCartney J W, Pearson R. Segmental framework matrix: master cast verification, corrected cast guide, and analogue transfer template for implant-supported prostheses. J Prosthet Dent 1994; 71: 197-200.

12. Herbst $D$, Nel J C, Driessen $C H$, Becker P J. Evaluation of impression accuracy for osseointegrated implant supported superstructures. J Prosthet Dent 2000; 83: 555-561.

13. Hsu C C, Millstein P L, Stein R S. A comparative analysis of the accuracy of implant transfer techniques. J Prosthet Dent 1993; 69: 588-593

14. Inturregui J A, Aquilino S A, Ryther J S, Lund PS. Evaluation of three impression techniques for osseointegrated oral implants. J Prosthet Dent 1993: 69: 503-509.

15. Chee W W, Donovan T E. Poly (Vinyl Siloxane) impression materials: a review of properties and techniques. J Prosthet Dent 1992: 68: 728-732.

16. Beyak B L, Chee W W. Compatibility of elastomeric impression materials for use as soft tissue casts. J Prosthet Dent 1996; 76: 510-514

17. Cho G C, Chee W W. Distortion of disposable plastic stock trays when used with putty vinyl polysiloxane impression materials. J Prosthet Dent 2004; 92: 354-358.

18. Cho G C, Donovan T E, Chee W W, White S N. Tensile bond strength of polyvinyl siloxane impressions bonded to a custom tray as a function of drying time: Part I. J Prosthet Dent 1995; 73: 419-423

19. Derbabian $K$, Chee W W. Simple tools to facilitate communication in esthetic dentistry. J CalifDent Assoc 2003; 31: 537-542

20. Buskin R, Salinas TJ Transferring emergence profile created from the provisional to the definitive restoration. Pract Perio Aest Dent 1998; 10: 1171-1179.

21. Stumpel LJ, Haechler W, Bedrossian E. Customized abutments to shape and transfer peri-implant soft-tissue contours. J Calif Dent Assoc 2000; 28: 301-309.

22. Neale $D$, Chee W W. Development of implant soft tissue emergence profile: A technique. J Prosthet Dent 1994 71:364-368.

23. Chee W W, Cho G C, Ikoma M M, Arcidiacono A. A technique to replicate soft tissues around fixed restoration pontics on working casts. J Prosthodont 1999; 8: 44-46.

24. Chee W W, Cho G C, Ha S. Replicating soft tissue contours on working casts for implant restorations. J Prosthodont 1997; 6 : 218-220. 